\title{
PENINGKATAN KESADARAN HUKUM MASYARAKAT DALAM
}

RANGKA PENANGANAN DAN PENCEGAHAN COVID-19 MELALUI GERAKAN MILENIAL LAWAN COVID-19 DI SULAWESI TENGGARA

${ }^{1}$ Herman, ${ }^{2}$ Safril Sofwan Sanib, ${ }^{3}$ Heryanti, ${ }^{4}$ Rahman Hasima

${ }^{1234}$ Program Studi IImu Hukum Fakultas Hukum Universitas Halu Oleo

Email: rahmanhasima@uho.ac.id

\section{RINGKASAN}

Tujuan kegiatan pengabdian terintegrasi KKN Tematik ini adalah untuk meningkatkan pemahaman dan pengetahuan masyarakat akan pentingnya kesadaran hukum masyarakat dalam rangka penanganan dan pencegahan covid-19 melalui gerakan Milenial Lawan Covid19 di Sulawesi Tenggara. Program kerja yang dilakukan adalah sosialisasi atau penyuluhan kepada masyarakat mengenai penanganan dan pencegahan covid-19 melalui Gerakan Milenial Lawan Covid-19 seperti pencegahan penyebaran covid-19, penerapan social distancing atau physical distancing, pembatasan sosial berskala besar (PSBB), penerapan new normal melalui poster dan video dan membagikan masker dan hand sanitizer serta penerapan perilaku hidup bersih sehat kepada masyarakat. Metode Pelaksanaan yang digunakan adalah 1) metode pendekatan perorangan, mahasiswa KKN Tematik secara langsung berhubungan dengan sasaran perorangan. Cara yang dapat ditempuh antara lain kunjungan kerumah warga, 2) metode pendekatan kelompok yakni mahasiswa berhubungan dengan kelompok sasaran dengan cara sosialisasi kepada masyarakat, pembinaan masyarakat dengan tetap memperhatikan protokol kesehatan seperti menjaga jarak dan tidak mengumpulkan massa dalam jumlah banyak. Sosialisasi dilakukan dengan menggunakan media poster dan video. Hasilnya menujukan bahwa tingkat pemahaman dan pengetahuan masyarakat melalui media poster dan video dalam pencegahan dan penanganan covid-19 di Sulawesi Tenggara baik dan kegiatan pengabdian tentang penanggulangan covid-19 sangat membantu dan memberikan kemudahan bagi masyarakat Sulawesi Tenggara dalam mencegah penyebaran covid-19.

\section{Kata kunci: Kesadaran Hukum; Covid-19; Milenial}

\section{A. Analisis Situasi}

WHO pertama kali mengumumkan covid-19 sebagai pandemi global pada 11 Maret 2020 jumlah infeksi diseluruh dunia telah mencapai lebih dari $121.000 .^{1}$ Alih-alih Indonesia masih merasa aman dari wabah virus yang sudah melumpuhkan sebagian negara-negara di dunia, Presiden Joko Widodo pada awal Maret lalu yang tadinya

\footnotetext{
${ }^{1}$ World Health Organization, WHO Director-General's opening remarks at the media briefing on COVID-19 - 11 March 2020, diakses dari https://www.who.int/dg/speeches/detail/who-director-general-s-openingremarks-at-the-media-briefing-on-covid-19-11-march-2020 pada 16 Maret 2020
} 
membuat masyarakat berada di zona nyaman, harus mengakui kekalahan dengan adanya laporan kasus covid-19 yang disebabkan oleh virus SARS-Cov-2 atau yang lebih dikenal dengan sebutan virus Corona.

Penyebaran virus yang tak pernah diantisipasi akan sampai di Indonesia hingga kini masih berlanjut. Pusat Pemodelan Matematika dan Simulasi Institut Teknologi Bandung mempekirakan pandemi ini akan mencapai puncaknya pada akhir Maret dan berakhir pada pertengahan April 2020. Bahkan dengan kedinamisan data yang ada, prediksi tersebut bisa saja berubah. ${ }^{2}$ Data ini tentunya bukan untuk membuat kepanikan di tengah masyarakat, namun lebih untuk membuat masyarakat waspada dan memberikan gambaran bagi pemerintah dalam penanganannya. Yakni penanganan secara kompehensif, khususnya untuk mencegah penyebaran yang lebih luas agar jumlah infeksi dapat ditekan.

Salah satu daerah yang terdampak covid-19 adalah wilayah Provinsi Sulawesi Tenggara. Berdasarkan peta persebaran covid-19 di Provinsi Sulawesi Tenggara pertanggal 2 Mei 2020 bahwa jumlah positif Covid-19 adalah 62 orang terdiri dari pasien positif yang sembuh berjumlah 11 orang, meninggal 2 orang dan dalam perawatan 49 orang, Dalam Pemantauan (ODP) berjumlah 247 orang, Pasien Dalam Pengawasan (PDP) berjumlah 13 orang dan Orang Tanpa Gejala (OTG) berjumlah 670 orang. ${ }^{3}$ Provinsi Sulawesi Tenggara terdiri dari 17 Kabupaten/Kota dan yang masuk wilayah zona merah berjumlah 8 Kabupaten/Kota antara lain Kota Kendari, Kota Baubau, Kabupaten Konawe, Kabupaten Konawe Selatan, Kabupaten Muna, Kabupaten Kolaka Timur, Kabupaten Kolaka Utara dan Kabupaten Bombana. Sedangkan 9 Kabupaten lain yang tidak memiliki kasus covid-19 adalah Kabupaten Buton, Kabupaten Buton Utara, Kabupaten Buton Tengah, Kabupaten Buton Selatan, Kabupaten Wakatobi, Kabupaten Kolaka, Kabupaten Konawe Kepulauan, Kabupaten Muna Barat dan Kabupaten Konawe Utara.

Berdasarkan uraian diatas, bahwa kasus covid-19 di Sulawesi Tenggara terus bertambah sehingga diperlukan upaya untuk membantu pemerintah daerah dalam penanganan dan

2 CNN, ITB: Puncak Corona RI Akhir Maret, Berakhir Tengah April 2020, 2020, diakses dari https://www.cnnindonesia.com/teknologi/20200319142837-199-484974/itb-puncak-corona-ri-akhirmaret-berakhir-tengah-april-2020 pada 25 Maret 2020

${ }^{3}$ Data dari Dinas Kesehatan Provinsi Sulawesi Tenggara tertanggal 2 Mei 2020 pukul 09.00 wita 
pencegahan penyebaran covid-19 melalui kegiatan pengabdian masyarakat terintegrasi KKN Tematik untuk mengurangi dan menekan penyebaran covid-19.

Beberapa permasalahan yang dihadapi oleh pemerintah daerah dalam penanganan dan pencegahan covid-19 adalah kurangnya kesadaran hukum masyarakat karena tidak menghiraukan himbuan dari pemerintah pusat maupun daerah. Secara spesifik dapat dijabarkan masalah yang dialami oleh mitra yaitu sebagai berikut: (a) kurangnya kesadaran masyarakat tentang covid-19 dan penerapan social distancing atau physical distancing , (b) kesadaran masyarakat menggunakan masker dan hand sanitizer pada saat keluar rumah masih rendah, (c) masih kurangnya kesadaran masyarakat dalam menerapkan perilaku hidup bersih dan sehat dan (d) pengetahuan masyarakat tentang penerapan pembatasan sosial berskala besar (PSBB) dan new normal masih kurang.

Adapun tujuan kegiatan pengabdian kepada masyarakat terintegrasi KKN Tematik ini adalah untuk meningkatkan pemahaman dan pengetahuan masyarakat akan pentingnya kesadaran hukum dalam rangka penanganan dan pencegahan covid-19 melalui gerakan Milenial Lawan Covid-19 di lokasi masing-masing peserta KKN Tematik.

Solusi permasalahan yang ditawarkan dalam kegiatan pengabdian kepada masyarakat ini dilakukan dengan cara sosialisasi atau penyuluhan kepada masyarakat mengenai penanganan dan pencegahan covid-19 melalui Gerakan Milenial Lawan Covid19 tentang pencegahan penyebaran covid-19, penerapan social distancing atau physical distancing, pembatasan sosial berskala besar (PSBB), penerapan new normal melalui poster dan video dan membagikan masker dan hand sanitizer serta penerapan perilaku hidup bersih sehat kepada masyarakat yang dilaksanakan oleh Mahasiswa Peserta KKN Tematik Universitas Halu Oleo di lokasi masing-masing peserta KKN Tematik. Dilakukan dengan metode pendekatan langusung, mahasiswa peserta KKN Tematik secara langsung berhubungan dengan masyarakat dengan kunjungan kerumah warga dengan tetap memperhatikan protokol kesehatan seperti menjaga jarak dan tidak mengumpulkan massa dalam jumlah banyak. 


\section{B. METODE PELAKSANAAN}

Penyampaian pemahaman hukum kepada kelompok masyarakat harus diberikan dengan metode yang tepat dengan memperhatikan kondisi sosial dan budaya masyarakat, berikut beberapa metode yang akan diterapkan, Pertama; metode pendekatan perorangan, mahasiswa KKN Tematik secara langsung berhubungan dengan sasaran perorangan. Cara yang dapat ditempuh antara lain kunjungan kerumah warga, Kedua; metode pendekatan kelompok yakni mahasiswa berhubungan dengan kelompok sasaran dengan cara sosialisasi kepada masyarakat, pembinaan masyarakat dengan tetap memperhatikan protokol kesehatan seperti menjaga jarak dan tidak mengumpulkan massa dalam jumlah banyak. Sosialisasi dilakukan dengan menggunakan media poster dan video.

\section{HASIL DAN PEMBAHASAN}

Penerbitan regulasi dalam rangka penanganan penyebaran Covid 19 merupakan upaya untuk mendukung keberadaan Undang-Undang Nomor 24 Tahun 2007 yang menetapkan wabah penyakit sebagai salah satu bencana non-alam yang perlu dikelola potensi ancamannya. Atas regulasi-regulasi tersebut maka upaya-upaya yang saat ini dilakukan oleh mahasiswa dengan cara sosialisasi dalam bidang hukum dan kesehatan mengenai :

\section{a. Bidang Hukum}

\section{1) Sosialisasi Kebijakan Pemerintah Tentang Covid-19}

Setelah kami melakukan survei masalah, kami menemukan beberapa permasalahan dalam menjalankan prosedur kebijakan pemerintah yang dialami oleh masyarakat Kelurahan Bungkutoko yakni terkait Prosedur physical distancing dalam kehidupan bermasyarakat dimana penyuluhan tersebut dilaksanakan pada hari senin, 20 juni 2020. Tujuan dari adanya Penyuluhan tersebut adalah untuk memberikan pemahaman kepada Masyarakat terkait masalah yang timbul akibat kebijakan pemerintah tersebut dengan memasang spanduk tentang pencegahan covid-19. 


\section{2) Sosialisasi Tentang Social Distancing/ Physical Distancing}

Sosial distancing merupakan salah satu cara pencegahan penyebaran covid-19 agar mengurangi penularan virus dengan menghindari keramain serta menjaga jarak antar manusia. Cara ini tak hanya mencegah seseorang terkena virus tapi juga menghindari "carrier atau pembawa virus" menularkan kepada orang lain. Hal ini merupakan salah satu dari program kerja kami mahasiswa KKN Tematik 2020 untuk mensosialisasikan apa itu social distancing dan bagaimana cara penerapannya kepada masyarakat. Sosialisasi dilakukan di daerah sesuai domisili dari peserta KKN Tematik yakni di Kota Kendari (Kel. Tipulu \& Kel. Bungkutoko) dengan menggunakan media poster.

3) Sosialisasi Tentang PSBB

PSBB merupakan singatan dari Pembatasan Sosial Berskala Besar yang dianggap mampu mempercepat penanggulangan sekaligus mencegah penyebaran corona yang semakin meluas di Indonesia. Namun masyarakat daerah belum sepenuhnya memahami apa itu PSBB, sehingga mahasiswa KKN Tematik turun ke masyarakat untuk menyosialisasikan apa itu PSBB.

\section{4) Penerapan New Normal}

New normal adalah skenario untuk mempercepat penanganan covid-19 dalam aspek kesehatan dan sosial ekonomi. New normal dikatakan sebagai cara hidup baru di tengan pandemi virus corona yang angka kesembuhannya makin meningkat. Beberapa daerah telah membuat aturan terkait penerapan new normal sambil terus melakukan upaya pencegahan covid-19, dalam hal ini mahasiswa KKN Tematik 2020 ikut andil bagian dalam membantu pemerintah setempat untuk menjelaskan kepada masyarakat terkait penerapan dari new normal tersebut.

\section{b. Bidang Kesehatan}

1) Sosialisasi Pengetahuan Tentang Covid-19

Penyuluhan mengenai apa itu covid-19 sangat penting untuk meningkatkan kesadaran masyarakat akan bahaya dari virus ini, dengan melakukan penyuluhan ini 
kami sangat memperhatikan protocol kesehatan dengan melakukannya secara door to door dan penyuluhan langsung kepada perangkat kelurahan.

2) Sosialisasi Gerakan Menggunakan Masker

Ditengah situasi pandemi seperti ini sangat perlu menggunakan masker dalam aktivitas kehidupan sehari-hari. Dengan hal ini kami sangat khawatir dengan keadaan masyarakat yang belum keseluruhan patuh dalam penggunaan masker, maka kami mengadakan sosialisasi mengenai pentingnya penggunaan masker dan tata cara menggunakan masker yang benar sesuai daerah kami berdomisili.

Selain itu, Guna mengikuti protokol kesehatan yang ditetapkan oleh pemerintah, dan dengan tujuan saling melindungi diri dan masyarakat dari covid-19 kami secara sukarela membagikan masker kepada masyarakat di beberapa lokasi KKN Tematik sesuai domisili dari para peserta KKN.

3) Gerakan Menggunakan Antiseptik / Handsanitizer

Dalam melakukan Program ini kami mahasiswa KKN Tematik 2020 turun ke masyarakat untuk melakukan simulasi penggunaan handsanitizer yang benar dan apa saja bahan yang harus terkandung dalam handsanitizer, dalam hal ini kami memperagakan cara penggunaan handsanitizer dengan baik sesuai aturan atau tata cara yang telah ditetapkan.

4) Sosialisasi Perilaku Hidup Bersih dan Sehat

Pola hidup berdih dan sehat adalah semua perilaku kesehatan yang dilakukan atas kesadaran sehingga anggota keluarga atau keluarga dapat menolong dirinya sendiri dibidang kesehatan dan berperan aktif dalam kegiatan-kegiatan kesehatan di masyarakat. Seperti yang dilakukan mahasiswa KKN Tematik di beberapa daerah sesuai domisili dari peserta KKN dengan turun langsung kemasyarakat untuk mensosialisasikan tata cara perilaku hidup bersih dan sehat.

Hasil evaluasi pelaksanaan kegiatan pengabdian penanggulangan covid-19 ini dilakukan mulai dari tahap sosialisasi dengan menggunakan media poster dan video sampai dengan berpartisipasi secara langsung seperti membagikan masker dan membersihkan halaman rumah sebagai wujud penerapan perilaku hidup bersih dan sehat (PHBS). Hasil evaluasi tersaji dalam tabel 1 berikut ini. 
Tabel 1. Hasil Evaluasi Pelaksanaan Kegiatan Pengabdian

\begin{tabular}{|c|l|c|}
\hline No. & \multicolumn{1}{|c|}{ Aspek } & Presentase \\
\hline 1 & $\begin{array}{l}\text { Pemahaman dan pengetahuan atas } \\
\text { kegiatan yang dilaksanakan dengan } \\
\text { menggunakan media poster dan video }\end{array}$ & $85 \%$ \\
\hline 2 & $\begin{array}{l}\text { Partisipasi masyarakat selama kegiatan } \\
\text { pengabdian berlangsung }\end{array}$ & $90 \%$ \\
\hline 3 & $\begin{array}{l}\text { Respon masyarakat terhadap kegiatan } \\
\text { pengabdian }\end{array}$ & $85 \%$ \\
\hline 4 & $\begin{array}{l}\text { Kegiatan pengabdian tersebut menarik } \\
\text { minat masyarakat }\end{array}$ & $85 \%$ \\
\hline
\end{tabular}

Hasil evaluasi kegiatan pengabdian ini masyarakat mampu memahami dan mengetahui seluruh kegiatan pengabdian dengan menggunakan media poster dan video yang dilaksanakan dalam pencegahan dan pengangan covid-19 di Sulawesi Tenggara yang ditunjukan dengan hasil yang baik. Hal ini dapat dilihat dari antusias masyarakat dengan memberikan respon positif atas kegiatan yang dilakukan terkait dengan pencegahan covid-19 serta dapat menarik minat masyarakat dan mengharapkan kegiatan seperti ini agar terus berlangsung secara berkesinambungan.

\section{KESIMPULAN}

Berdasarkan hasil kegiatan pengabdian terintegrasi KKN tematik disimpulkan bahwa peserta KKN Tematik telah melaksanakan program kerja yaitu sosialisasi atau penyuluhan kepada masyarakat mengenai penanganan dan pencegahan covid-19 melalui Gerakan Milenial Lawan Covid-19 antara lain pencegahan penyebaran covid-19, penerapan social distancing atau physical distancing, pembatasan sosial berskala besar (PSBB), penerapan new normal melalui poster dan video dan membagikan masker dan hand sanitizer serta penerapan perilaku hidup bersih sehat kepada masyarakat. Hasilnya menujukan bahwa tingkat pemahaman dan pengetahuan masyarakat melalui media poster dan video dalam pencegahan dan penanganan covid-19 di Sulawesi Tenggara baik dan kegiatan pengabdian tentang penanggulangan covid-19 sangat membantu dan memberikan kemudahan bagi masyarakat Sulawesi Tenggara dalam mencegah penyebaran covid-19. Namun dibutuhkan bantuan dari pemerintah dalam penanganan dan pencegahan covid-19 seperti pembagian masker dan hand sanitizer dan peran serta 
masyarakat agar senantiasa memiliki kesadaran hukum akan pentingnya penanganan dan pencegahan covid-19 di wilayah masing-masing.

\section{UCAPAN TERIMAKASIH}

Ucapan terima kasih kepada Lembaga Penelitian dan Pengabdian Pada Masyarakat Universitas Halu Oleo, Pemerintah Kota Kendari (Kelurahan Tipulu dan Kelurahan Bungkutoko), Kabupaten Muna (Kelurahan Laende), Kabupaten Wakatobi (Desa Mola Selatan), Kabupaten Kolaka Utara (Patowonua), Kabupaten Konawe (Kelurahan BoseBose), Kabupaten Pangkajene Kepulauan (Kelurahan Tonasa) dan Kabupaten Bombana yang menjadi lokasi peserta KKN Tematik, peserta mahasiswa KKN Tematik dan semua pihak yang telah membantu pelaksanaan kegiatan ini. Semoga kegiatan ini dapat bermanfaat bagi semua pihak dalam rangka peningkatan mutu kehidupan sosial masyarakat dan pengambangan tridharma perguruna tinggi yang sesuai dengan visi dan misi Universitas Halu Oleo.

\section{DAFTAR PUSTKA}

Kementerian Kesehatan RI, Direktorat Jenderal Pencegahan dan Pengendalian Penyakit (P2P) 2020. Pedoman Kesiapsiagaan Menghadapi Coronavirus Disesase (Covid19).

Badan Pusat Statistik Kota Kendari. Kendari Dalam Angka Tahun 2019.

World Health Organization, WHO Director-General's opening remarks at the media briefing on COVID-19 - 11 March 2020, diakses dari https://www.who.int/dg/speeches/detail/who-director-general-s-openingremarks-at-the-media-briefing-on-covid-19-11-march-2020 pada 16 Maret 2020

CNN, ITB: Puncak Corona RI Akhir Maret, Berakhir Tengah April 2020, 2020, diakses dari https://www.cnnindonesia.com/teknologi/20200319142837-199-484974/itbpuncak-corona-ri-akhir-maret-berakhir-tengah-april-2020 pada 25 Maret 2020

https://www.kendarikota.go.id/ akses tanggal 23 April 2020 